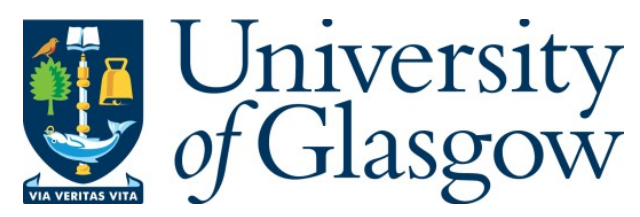

Capsada-Munsech, Q. and Valiente, O. (2020) Sub-national variation of skill formation regimes: a comparative analysis of skill mismatch across 18 European regions. European Education, 52(2), pp. 166-179.

(doi: $10.1080 / 10564934.2020 .1723421)$

This is the Author Accepted Manuscript.

There may be differences between this version and the published version. You are advised to consult the publisher's version if you wish to cite from it.

https://eprints.gla.ac.uk/208931/

Deposited on: 3 February 2020

Enlighten - Research publications by members of the University of Glasgow http://eprints.gla.ac.uk 


\section{Sub-national variation of skill formation regimes: A comparative analysis of skill mismatch across 18 European regions}

Abstract: This article adopts the skill ecosystem approach to the comparative analysis of skill mismatch across European regions within different skill formation regimes. Institutional arrangements of skill formation regimes are designed at national level. However, they are enacted in regions with very different labour market and socioeconomic conditions, which mediate the relationship between the institutional setting and its effects on the mismatch between the supply and demand of skills in a given region. Our analysis draws on quantitative and qualitative data from a EU Horizon 2020 project on lifelong learning policies for young adults that compares 18 regions in nine European countries. The data analyses show the importance of regional demand side factors in explaining skill shortages and skill surplus, and the coexistence of low-skill and high-skill equilibria in urban regions with high levels of skill polarisation. Skill formation regimes present divergent effects on skill mismatch depending on the availability of jobs in the region and the level of skills demanded by the local economy. These findings suggest that combining skill formation regime and skill ecosystem approaches in comparative education research can provide better suited explanations of skill mismatch at regional and sectoral level.

Keywords: skill ecosystem; skill mismatch; skill formation; youth unemployment; functional region

\section{Introduction}

Skills are one of the most valued assets in contemporary societies, as higher skills levels are associated with better economic, social, health and political participation outcomes (OECD, 2012). For those experiencing the transition from education to work for the first time, the skills gained via the education and training system are considered as key in securing employment. However, the skills provided by national education and training systems are later deployed by youth across regions with different socioeconomic structures. Thus, depending on the regional labour market demands, the utility of the skills acquired by young people is likely to vary regionally. Before the 2008 global financial crisis, young people already struggled to find a suitable job linked to their education and skills, and since then ongoing challenges have become even larger given the less favourable economic and social conditions.

Most lifelong learning (LLL) policies targeting young people's transitions from education to work are aimed at improving youths' knowledge and skills, thus increasing their employability and ability to fit labour market demands. These policies have traditionally adopted a Human Capital Theory (HCT) perspective (Becker, 1964; OECD, 2001), assuming that an individual's good foundation of knowledge and skills will translate into a full utilisation of these skills in the labour market. Contrary to this assumption, workers' skills are not always fully utilised in the labour market. Skill mismatch (Froy et al., 2009) such as skill shortages - which materialise in hard to fill vacancies - and skill surpluses - producing over-qualification and unemployment - serve as vivid examples of skill underutilisation (Lauder et al., 2012). In turn, these skill mismatches affect largely socially disadvantaged groups (e.g. young people, women, ethnic minorities). 
This article adopts the skill ecosystem approach (Buchanan et al., 2017; Dalziel, 2017) to the comparative analysis of skill mismatch across 18 regions in nine European countries. This approach has two fundamental advantages over previous frameworks to the study of skill mismatch. Firstly, by considering the interaction between supply (education) and demand (labour market) explanatory factors, it overcomes the 'supply side fundamentalism' that has prevailed in HCT research. Secondly, by focusing on sub-national levels of analysis, it avoids the 'methodological nationalism' of comparative research on skill formation regimes (Busemeyer and Trampusch, 2012). Drawing on quantitative and qualitative data collected by a comparative EU Horizon 2020 research project on LLL policies for young adults, our article aims at providing a better understanding of the labour market and socioeconomic factors that mediate the relationship between skill formation regimes and skill mismatch across European regions.

\section{The skill ecosystem approach to skill mismatch}

Research on skill mismatch has traditionally been dominated by economistic and functionalist accounts of education and training that have mainly focused on the supply of skills (Almeida et al., 2012). The underlying assumption behind these approaches is that the educational offer should respond to the needs of employers and that every mismatch between the skills of the workforce and their labour market situation can be explained by failures in education planning and delivery, and/or by the poor investment of individuals in their education and training (McQuaid and Lindsay, 2005). The main perspective within these approaches is HCT (Becker, 1964; Mincer, 1974; Schultz, 1961). Under this perspective, the 'invisible hand' of the market will perfectly match the supply and demand of skills in the long term, as both workers and employers will aim to fully utilise the existing skills to maximise their returns. Thus, skill mismatch is considered a temporary problem that can be addressed through better labour market information and a greater labour market orientation of education provision.

One of the first criticisms of HCT came from Signalling Theory (Spence, 1973), which argues that the education system provides credentials that signal to employers what a person is able to do. The skills level, type and quality vary across people with the same credentials, or can even be similar to others that do not hold these credentials. However, credentials are used by employers as a proxy for the trainability and productivity of individual workers. This 'sheepskin effect' and competition among workers for the best job that matches their education creates credential inflation and, in turn, skill mismatch such as overqualification (McGuinness, 2006). Despite the importance of this critique for research into the economics of education and labour, Signalling Theory does not constitute a fundamental challenge to HCT because both of them try to explain skill mismatch entirely through supply side factors (i.e. educational choices, disjunction between qualifications and skills).

Sociological and institutionalist approaches have questioned most of the assumptions of HCT and have focused on demand side factors and on the relationship between skill mismatch and social inequalities. Under these approaches, individuals have very limited power to influence their labour market situation, as socioeconomic forces privilege or disadvantage some social groups over the rest. Reproduction Theory in the sociology of education understands educational institutions as mechanisms that reproduce and reinforce inequalities between individuals and social groups. The fact that young people from different social classes systematically achieve unequal labour market outcomes is explained by pre-existing 'cultural capital' inequalities passed on through the family and certified by the education and training system (Bourdieu, 1984, 1986). Institutionalist approaches in the sociology of work complement this view by examining how social inequalities are reproduced in the labour market. Dual Labour Market Theory 
(Doeringer and Piore, 1985) shows that labour markets are institutionally segmented. These offer unequal job opportunities to those that have access either to the primary segment (i.e. high-skilled and high-paid jobs, with career progression opportunities and stability to those with better credentials and networks), or to the secondary segment (i.e. low-skilled and low-paid jobs, with unstable contracts and limited training possibilities). Workers are sorted into either one segment of the labour market or the other depending on their education, but also their race, gender and class (Bowles and Gintis, 1976). Beyond individual education and social background, employment possibilities very much depend on what employers are looking for, the amount of jobs available and the pace of matching these with the supply of education and skills (Lauder et al., 2012).

Aiming to bring supply and demand side explanations together, the idea of 'skill ecosystem' was first coined as a response to the 'supply side fundamentalism' of mainstream approaches to the study of skill mismatch. Its origin comes from the study of the necessary conditions for the emergence and functioning of highly-innovative and highly-skilled technological clusters. Skill ecosystem was initially defined as " $a$ regional or sectoral social formation in which human capability is developed and deployed for productive purposes" (Finegold, 1999). The departing assumptions under this approach are: 1 ) the market by itself rarely generates an equilibrium between the supply and demand of skills (Anderson and Warhurst, 2012); 2) certain skill equilibria (e.g. low-skill equilibrium) are not necessarily desirable from a social perspective (Finegold and Soskice, 1988); and 3) moving to a high-skill equilibrium requires a high level of coordination that is extremely context-dependent (Payne, 2008). More recently, Dalziel (2015) outlined a framework for the skill ecosystem approach based on the relationship between skill formation and skill utilisation. His approach focuses on the institutional and socioeconomic factors that shape the connections between the productive skills that workers are willing to deploy in the labour market and the skills demanded by employers as productive of value for their businesses. Therefore, skill mismatch will differ across skill ecosystems depending on the variation in their skill formation and utilisation systems, which is the focus of this article.

In comparative education research, Busemeyer and Trampusch (2012) contributed the most accomplished classification of skill formation regimes in advanced economies, paying particular attention to how the relationship between collective actors (i.e. employers, unions) and the state affects the financing and provision of skills in different countries. Taking as the starting point the paradox of collective action among firms (Crouch et al., 2001), they interrogate how institutional arrangements of skill formation facilitate the resolution of collective action problems typical of unregulated training markets. They suggest two dimensions of variation that are important to understand the different solutions to these collective action problems in vocational education and training (VET): the degree of firm involvement and the degree of public commitment. A higher involvement of firms in training might imply a higher specificity of training, while a higher commitment of the state will go beyond financial support to include the certification and standardisation of training, as well as the recognition of VET as a viable alternative to academic higher education. The combination of these two dimensions results in a $2 \times 2$ typology, in which countries are classified according to four types of solutions: 1 ) the liberal solution of narrow on-the-job training (e.g. the United Kingdom); 2) the segmentalist solution of firms' self-regulation (e.g. Japan); 3) the statist solution of state-run training (e.g. France); and 4) the collective solution where firms, employers' and workers' associations, and the state collaborate in providing and financing skills (e.g. Germany). According to this classification, economies that combine high public commitment and high level of employers' involvement in skill formation will tend to be associated with high-intermediate skills 
and a high level of adjustment between the skills of the workforce and job requirements (Estevez-Abe et al., 2001).

Skill formation regimes and skill ecosystem are both relatively novel analytical contributions to the study of skill mismatch. In the case of the skill formation regimes literature, most of the comparative studies still take the nation-state as primary unit of analysis. While education and training systems tend to be designed and monitored at the national level, these are usually enacted and implemented across socioeconomically diverse regions with very different employment opportunities and labour market demands. Therefore, the relationship between skill formation and utilisation are likely to vary largely across regions and sectors within countries, as well as the resulting skill mismatch. The skill ecosystem approach has received more attention among policy circles and applied research than from critical scholars (Anderson and Warhurst, 2012; Buchanan et al., 2010; OECD, 2012). There are several empirical studies using the skill ecosystem framework for the analysis of regions or sectors in Australia (Buchanan et al., 2001, 2017), New Zealand (Dalziel, 2015), the United Kingdom (Hodgson and Spours, 2013, 2015; Payne, 2008, 2009) and the United States (Finegold, 1999), but there is a clear gap in comparing regions across countries. By combining the skill formation regimes and the skill ecosystem approaches in the comparative analysis of skill mismatch across European regions, our article aims at addressing these gaps and providing a better understanding of the institutional and socioeconomic factors that shape the relationship between skill formation and skill mismatch at the sub-national level.

\section{Data \& Methods}

We draw on quantitative and qualitative data from a large EU H2O2O research project on LLL policies for young adults involving nine European countries. The countries under study represent geographical and welfare state diversity across Europe: Scandinavian Europe (Finland), Liberal Europe (Scotland-UK), Eastern Europe (Bulgaria, Croatia), Central Europe (Austria, Germany) and Southern Europe (Italy, Portugal, and Spain). For each country, local research teams selected two contrasting regions (18 regions in total) based on key socioeconomic indicators (e.g. household income, educational level, employment rate).

Using aggregate quantitative data from official statistical sources (i.e. Eurostat and OECD), we first map these countries against the typology of skill formation regimes (Busemeyer and Trampusch, 2012). We also provide a comparative description of relevant socioeconomic differences at the regional level (NUTS ${ }^{1}$ $2^{2}$ ) affecting young adults across regions under study. While for the quantitative data we are forced to use the NUTS 2 classification due to data availability, in the qualitative analysis our units of analysis are Functional Regions (FRs), defined and conceptualised as:

A region organised by functional relations that are maximised within the region (maximisation of intra-regional flows) and minimised across its borders (minimisation of inter-regional flows or interactions), so that the principles of internal cohesiveness and external separation regarding the intensities of spatial flows or interactions are met. (Klapka et al., 2013)

\footnotetext{
${ }^{1}$ Nomenclature of Territorial Units of Statistics (NUTS) of the European Union.

${ }^{2}$ See Table 1 for a detailed correspondence between the regions under study and NUTS 2 .
} 
The employment of the FR approach for the qualitative analysis allows us to go beyond the geographical, historical and administrative boundaries (static) that usually characterise statistical data, emphasising the organisation of social and economic activities (functional) in a territory and the interactions among actors interviewed. In practice, most local teams first selected and administrative unit (e.g. municipality) and then extended or curtailed the border region to capture the interdependence flows (e.g. train network, route connections).

Given the scarcity of comparable quantitative data on skill mismatch at subnational level, we adopt an analytical qualitative approach to identify the main regional skill mismatch and challenges affecting young adults across skill ecosystems. We use three methods to address this objective: desk-based review of academic literature, semi-structured interviews with key regional actors (i.e. policymakers, employers' representatives, trade unions, skills agencies), and a review of the grey literature (i.e. policy documents, reports) in the selected regions. In total, we base our analysis in 81 semi-structured interviews - four to five on average per region - and 129 documents - seven on average per region ${ }^{3}$. Semi-structured interviews with key regional actors aimed at identifying the main regional challenges concerning LLL policies for youth in vulnerable situations. The main areas covered in the interviews were: 1) regional challenges in terms of skill formation; 2) policy orientations of LLL policies; 3) governance arrangements between policy actors; and 4) implications of skill mismatch for the living conditions of young people in the region.

A qualitative content analysis of the texts (i.e. interview transcriptions and documents) was applied using thematic coding to identify the main topics related to the regional enactment of skill formation regimes and their effects on skill mismatch (Bowen, 2009; Schreier, 2012). Fourteen research teams across the nine countries under study replicated this exercise following the same analytical framework, data collection methods, analysis tools, and reporting guidelines. The interviews were conducted face-to-face between March and July 2017. Some of them were conducted by telephone or Skype call due to the remoteness of the area or the availability of the interviewees.

\section{Contextualisation of cases: 18 regions across nine European countries}

The nine European countries under study are classified across the typology of skill formation regimes based on the degree of public commitment and firms' involvement in skill formation in VET. We operationalise these concepts following previous research (Busemeyer and Iversen, 2011) ${ }^{4}$ using secondary statistical data. Figure 1 displays wide variation across the nine countries under study concerning their degree of public investment ( $Y$ axis) and firms' involvement in VET ( $X$ axis), as well as the youth unemployment rate (size of marker). Unsurprisingly, Germany (40\%) and Austria (33\%) display the largest share of students combining school- and work-based programmes (i.e. firms' involvement in VET), followed by the United Kingdom (UK) (22\%). The remaining countries present comparatively low or null levels of firms' involvement in VET: in Finland $10 \%$ of students in upper secondary education are enrolled

\footnotetext{
${ }^{3}$ See Tables 5 and 6 in the annex of the WP6 - International Report analysis of skill supply and demand for a detailed list of interviewees' affiliation and grey literature reviewed (http://www.youngadulllt.eu/publications/working-paper).

${ }^{4}$ Public commitment to VET is calculated using national public spending in upper secondary education as a share of GDP (average 2012-2015) times the share of students in upper secondary vocational education (2012) (Eurostat, 2012, 2017); Firms' involvement in VET is calculated using the share of students enrolled in combined school- and work-based programmes (OECD, 2015).
} 
in school- and work-based programmes, whereas in Spain these do not exist, and in Italy and Portugal these are rare and included in the main statistics as part of vocational programmes ${ }^{5}$. Concerning the degree of public investment in VET, Finland displays the largest investment, followed by Austria. The remaining countries show similar public spending on $\mathrm{VET}^{6}$, including Germany, which presents a similar level of spending as Portugal, Bulgaria and Spain.

Austria can be clearly classified as a collective skill formation regime (i.e. high public investment - high firm involvement), while Germany is at the edge between the collective and the segmentalist regime (i.e. the Japanese model). Although Germany is often held as the reference model for the collective skill formation category, according to our data and cases of study it comparatively displays the highest degree of firm involvement but a more limited public commitment. Similarly, the UK, which in the theoretical model is presented as an example of a liberal skill formation regime (i.e. low public investment - low firm involvement), appears to be at the boundaries of this category, displaying medium levels of public commitment and firms' involvement in VET. Finland is clearly positioned within the statist skill formation model (i.e. high public commitment - low firm involvement). Given the inexistent level of firms' involvement in VET and the low or medium public commitment/investment in VET, we classify the remaining countries (i.e. Bulgaria, Croatia, Italy, Portugal and Spain) within the liberal model. However, the inexistence (e.g. Spain) or limited practice of combined school- and work-based training (e.g. Italy and Portugal) limits the classification of Eastern and Southern European countries within these categories of skill formation regimes.

\footnotetext{
${ }^{5}$ No data available for Bulgaria and Croatia.

${ }^{6}$ No data available for Croatia.
} 
Figure1: Skill formation regimes by degree of public investment and firm involvement in VET

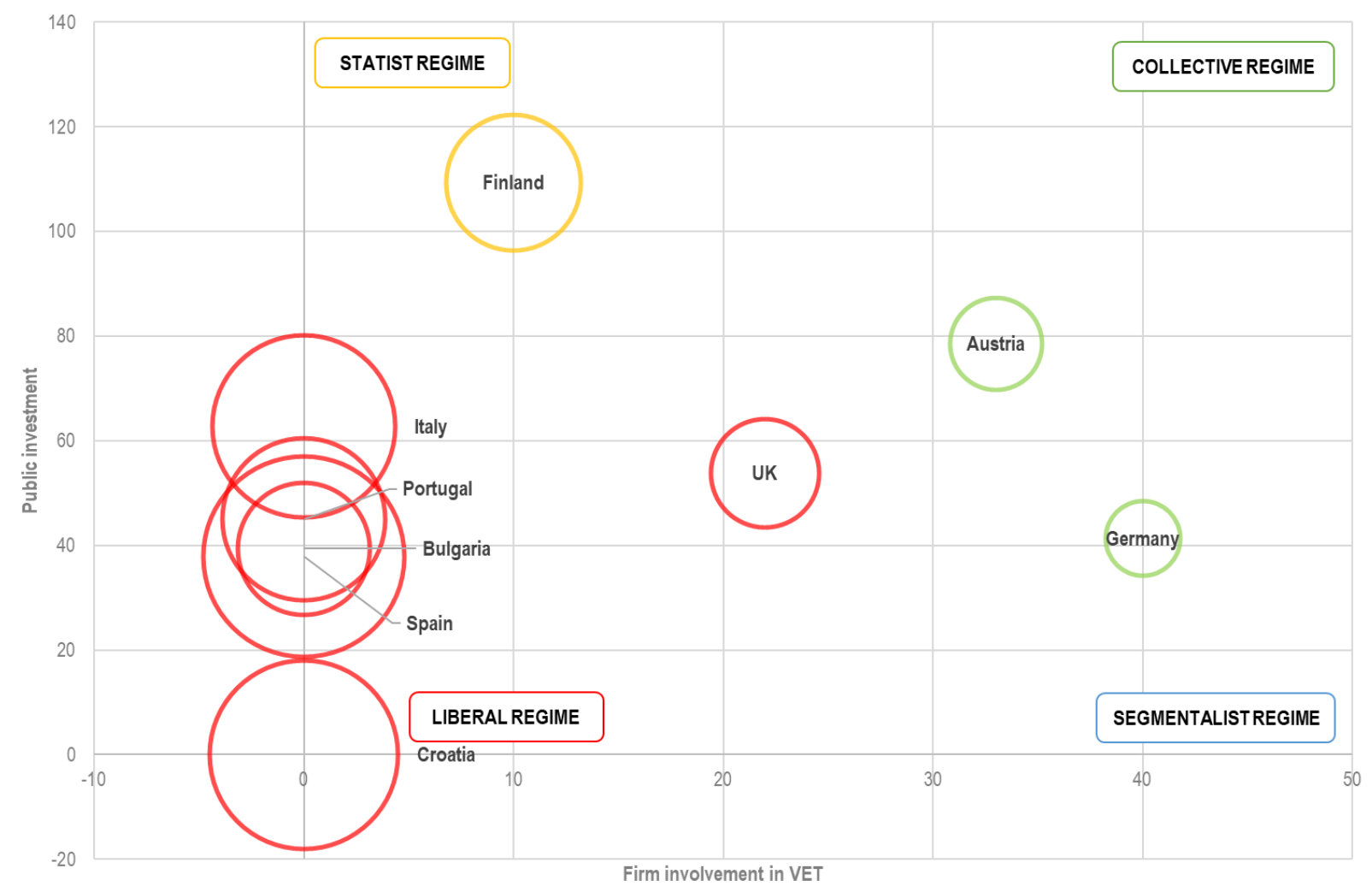

Source: authors' elaboration, based on Eurostat and OCED data.

Across the nine countries under study, we focus on two regions with contrasting socioeconomic contexts. Table 1 displays the correspondence between the selected FRs and NUTS 2, accompanied by key descriptive statistics capturing the supply and demand of youths' skills. It offers a comparable picture of the potential skill mismatch encountered across regions, as well as the potential explanatory factors (i.e. supply or demand side factors). Obvious differences are present across countries, but also across regions within and across countries. Starting with the supply side, we use the share of early leavers from education and training ${ }^{7}$ as a proxy for the youth skill supply. This share of youth with at most lower secondary education and not involved in further education ranges from $2.2 \%$ in the Croatian region of Jadranska Hrvatska (HR03) to $27.7 \%$ in the Spanish region of Andalucía (ES61). While the cross-regional differences at the national level are limited in some countries (e.g. $0.6 \%$ in Portugal, $1.1 \%$ in the UK), in others these are substantive (i.e. 7.1\% in Bulgaria, 5.5\% in Spain). We also use the share of the population aged 30-34 with tertiary education (ISCED ${ }^{8} 5-8$ ) as a proxy for the supply of highly-skilled youth. It ranges from a minimum of $23.2 \%$ in the Bulgarian region of Yuzhen tsentralen (BG42) to a maximum of $60.7 \%$ in North Eastern Scotland (UKM5). The smallest cross-regional differences is displayed in Croatia (1.6\%), while the largest is in Bulgaria (19.8\%).

\footnotetext{
${ }^{7}$ Early leavers from education and training (Eurostat, 2014a): share of 18-24 year olds who have completed at most lower secondary education and are not currently involved in any further education or training.

${ }^{8}$ International Standard Classification of Education (UNESCO, 2011).
} 
Moving to the demand side, we select the youth unemployment rate ${ }^{9}$ and the share of NEETs ${ }^{10}$ as indicators of skills demand and labour market opportunities. Youth unemployment figures range widely across regions, the lowest ranging from $7.9 \%$ in the Austrian region of Oberösterreich (AT31) to $61.5 \%$ in the Spanish region of Andalucía (ES61). The lowest cross-regional variation is observed in Portugal (0.5\%), while the largest is found in Spain (14.4\%). Concerning the share of NEETs, it ranges from $6.2 \%$ in the Austrian region of Oberösterreich (AT31) to $21.7 \%$ in the Bulgarian region of Yuzhen tsentralen (BG42). Limited cross-regional differences are displayed in Italy (0.1\%), while these are larger in Bulgaria (11.0\%).

Table 1: Correspondence between Functional Regions, regions at NUTS 2 and selected regional skills supply and demand indicators

\begin{tabular}{|c|c|c|c|c|c|c|c|c|c|c|c|}
\hline & & & & \multirow{2}{*}{\multicolumn{4}{|c|}{ SKILLS SUPPLY }} & \multirow{2}{*}{\multicolumn{4}{|c|}{ SKILLS DEMAND }} \\
\hline & & & & & & & & & & & \\
\hline Country & $\begin{array}{c}\text { Skill } \\
\text { Formation } \\
\text { Regime }\end{array}$ & $\begin{array}{c}\text { Functional Region } \\
\text { (Qualitative data) }\end{array}$ & $\begin{array}{l}\text { NUTS2 (20126 code) } \\
\text { (Quantitative data) }\end{array}$ & $\begin{array}{c}\text { Early Leavers } \\
\text { of Education } \\
\text { and Traning }\end{array}$ & \begin{tabular}{|c|} 
Cross-regional \\
$\Delta \%$ Early \\
Leavers of \\
Education and \\
Training \\
\end{tabular} & \begin{tabular}{|c|} 
Population \\
aged 30-34 with \\
ISCED 5-8
\end{tabular} & $\begin{array}{c}\text { Cross-regional } \\
\Delta \% \text { ISCED 5-8 }\end{array}$ & $\begin{array}{c}\text { Youth } \\
\text { unemployment } \\
\text { rate }\end{array}$ & $\begin{array}{c}\text { Cross-regional } \\
\Delta \% \text { youth } \\
\text { unemployment }\end{array}$ & $\begin{array}{l}\text { Neither in } \\
\text { Employment, } \\
\text { Education or } \\
\text { Training } \\
\text { (NEET) }\end{array}$ & $\begin{array}{c}\text { Cross-regional } \\
\Delta \% \text { NEET }\end{array}$ \\
\hline \multirow{2}{*}{ Austria } & \multirow{2}{*}{ Collective } & Upper Austria & Oberösterreich (AT 31) & 8.0 & \multirow{2}{*}{1.0} & 33.1 & \multirow{2}{*}{17.3} & 7.9 & \multirow{2}{*}{10.1} & 6.2 & \multirow{2}{*}{4.6} \\
\hline & & Vienna & Wien (AT 13) & 9.0 & & 50.4 & & 18.0 & & 10.8 & \\
\hline \multirow{2}{*}{ Bulgaria } & \multirow{2}{*}{ Eastern-Liberal } & Blagoevgrad & Yugozapaden (BG41) & 5.9 & \multirow{2}{*}{7.1} & 43.0 & \multirow{2}{*}{19.8} & 16.8 & \multirow{2}{*}{12.1} & 10.6 & \multirow{2}{*}{11.1} \\
\hline & & Plovdiv & Yuzhen tsentralen (BG42) & 13.0 & & 23.2 & & 28.9 & & 21.7 & \\
\hline \multirow{2}{*}{ Croatia } & \multirow{2}{*}{ Eastern-Liberal } & Istria-County & Jadranska Hrvatska (HR03) & 2.2 & \multirow{2}{*}{0.8} & 31.1 & \multirow{2}{*}{1.6} & 46.5 & \multirow{2}{*}{1.5} & 19.8 & \multirow{2}{*}{0.7} \\
\hline & & Osijek-Baranja & Kontinentalna Hrvatska (HR04) & 3.0 & & 32.7 & & 45.0 & & 19.1 & \\
\hline \multirow{2}{*}{ Finland } & \multirow{2}{*}{ Statist } & Kainuu & Pohjois-ja ltä-Suomi (Fl1D) & 7.9 & \multirow{2}{*}{4.5} & 40.9 & \multirow{2}{*}{2.9} & 22.1 & \multirow{2}{*}{0.8} & 10.8 & \multirow{2}{*}{0.2} \\
\hline & & Soutwest Finland & Etelä-Suomi (FI1C) & 12.4 & & 38.0 & & 22.9 & & 11.0 & \\
\hline \multirow{2}{*}{ Germany } & \multirow{2}{*}{ Collective } & Bremen & Bremen (DE50) & 14.0 & \multirow{2}{*}{3.8} & 39.4 & \multirow{2}{*}{2.8} & 15.3 & \multirow{2}{*}{5.9} & 9.4 & \multirow{2}{*}{2.9} \\
\hline & & Rhein Main & Darmstadt(DE71) & 10.2 & & 36.6 & & 9.4 & & 6.5 & \\
\hline Italy & Southern- & Genoa & Liguria (ITC3) & 13.6 & 07 & 31.3 & 54 & 45.0 & 138 & 16.2 & 01 \\
\hline Italy & Liberal & Milano & Lombardia (ITC4) & 12.9 & 0.1 & 25.9 & 5.4 & 31.2 & 13.8 & 16.1 & 0.1 \\
\hline Dotu & Southern- & Litoral Aentejano & Alentejo (PT 18) & 18.4 & 0 & 24.9 & 50 & 36.2 & 05 & 13.6 & 00 \\
\hline Portugal & Liberal & Vale do Ave & Norte (PT11) & 19.0 & 0.6 & 30.3 & 5.4 & 35.7 & 0.5 & 13.3 & 0.3 \\
\hline Snain & Southern- & Girona & Catalunya (ES51) & 22.2 & 55 & 47.0 & 147 & 47.1 & 144 & 18.4 & 26 \\
\hline Spain & Liberal & Málaga & Andalucia (ES61) & 27.7 & 5.5 & 32.3 & 14.1 & 61.5 & 14.4 & 21.0 & 2.6 \\
\hline United Kinadom & J theral & Aberdeen City \& Shire Region & North Eastern Scotland (UKM5) & 13.2 & 11 & 60.7 & 58 & 8.3 & 110 & 7.7 & 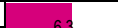 \\
\hline United Kingdom & Liberal & Glasgow City Region & West Scotland (UKM3) & 14.3 & 1.1 & 54.9 & 5.8 & 19.3 & 11.0 & 14.0 & \\
\hline
\end{tabular}

Note: all data corresponding to 2004.

Source: authors' elaboration, based on Eurostat data.

Thus, this contextualisation of the cases reveals the importance of empirically researching the differences between theoretical typologies of skill formation regimes and their sub-national variations. While countries differ in terms of public and private funding of VET, their classification into the different theoretical types does not capture well their current institutional arrangements (e.g. the UK, Germany). Furthermore, when comparing the skill supply and demand between regions within countries, large variation is observed in terms of youth unemployment rates and the percentage of highly-educated young people, suggesting the need for further interrogation of the factors explaining these regional differences.

\section{Regional skill mismatch and implications for social inequalities}

Based on the analysis of interviews with key regional stakeholders and the available grey literature, we classified the participating FRs according to four types of skill mismatch. Depending on the level of skills supply and demand, FRs are classified into four types of skill (mis)match: low-skill equilibrium, skill

\footnotetext{
${ }^{9}$ Youth unemployment rate (Eurostat, 2014b): people aged 15-24 without employment and actively looking for a job at the national and NUTS 2 levels. Data corresponding to 2014, except for Bremen (2011) and North East Scotland (2015).

${ }^{10}$ NEET (Eurostat, 2014c): young people aged 15 to 24 neither in employment nor in education and training.
} 
shortage, high-skill equilibrium, and skill surplus. These categories are not mutually exclusive, as FRs can display more than one skill (mis)match situation at the same time.

The most prevalent skill mismatch in policy discourses and reports is a shortage of skills (i.e. unsatisfied demand of skills). In some cases, skill shortages relate to the educational level (e.g. shortage of highlyskilled workers in Vienna, Austria) or to a specific period of the year (e.g. seasonal workers in Litoral Alentejano, Portugal). However, most commonly skill shortages are associated with specific industry sectors (e.g. oil and gas in Aberdeen, UK; ICT ${ }^{11}$ in Plovdiv, Bulgaria; ICT in Glasgow, UK; textile and agriculture in Vale do Ave, Portugal; metal and wood in Kainuu, Finland; marine and automobile in South West Finland; tourism and shipbuilding in Istria, Croatia). While in urban settings these skill shortages refer to specific sectors of the economy that have demonstrated great dynamism and innovation (e.g. ICT in Plovdiv, Bulgaria, and in Glasgow, UK), in non-urban settings they refer to one dominant industry in the region that is not attractive to the local young population (e.g. textile and agriculture in Vale do Ave, Portugal; metal and wood in Kainuu, Finland; marine and automobile in South West Finland; tourism and shipbuilding in Istria, Croatia) or that requires very specific skills that can only be recruited from abroad (e.g. oil and gas in Aberdeen, UK).

The other main type of skill mismatch experienced across several FRs is skill surplus (i.e. supply of skills that is not utilised or underutilised). Most commonly, skill surplus relates to a large number of highly educated graduates that cannot be absorbed by the local economy (e.g. Blagoevgrad, Bulgaria; Genoa, Italy; Istria and Osijek-Baranja, Croatia; Girona and Málaga, Spain). This over-supply of high skills in relation to employment opportunities usually translates into over-qualification (i.e. being employed in a job for which the worker's qualifications exceed those required for the job) among higher educated graduates (e.g. Blagoevgrad, Bulgaria; Genoa, Italy; Girona and Málaga, Spain) or into unemployment (e.g. Istria and Osijek-Baranja, Croatia). Interestingly, the FR of Bremen (Germany) is the only case that identifies a skill surplus of low-skill workers, as this region is increasingly attracting highly-skilled people. From a skill ecosystem perspective, the explanations for these skill mismatches are twofold: FRs lack employment opportunities for skilled workers because of the shortage of market opportunities (demand) or because young people are not investing in a type of education and skills that are valued by the local labour market (supply). Among the cases under study, the economic characteristics of the FRs reporting skill surplus clearly indicate that the demand side factors prevail in the explanation.

Some of the FRs experiencing skill surplus of highly educated people also experience a low-skill equilibrium (e.g. Girona and Málaga, Spain), suggesting that the significant market share of a low-skill sector (e.g. tourism) attracts low-skilled people as well as high-skilled people who are overqualified for the job. From a skill ecosystem perspective, the lack of employment opportunities (demand) offers a more relevant explanation of skill surplus than the alternative explanation related to young people's educational choices (supply). Conversely, in the FRs of Milan (Italy) and Rhein-Main (Germany) the lowskill equilibrium does not seem particularly related to specific industries within the economy, but generally to the service sector. The FR of Upper Austria used to be in a low-skill equilibrium and now seems to be upgrading to a middle/high-skill equilibrium thanks to investment in education and training.

Across the regions under study, high-skill equilibria occur mainly in specific sectors (e.g. ICT) in urban FRs (e.g. Bremen, Germany; Glasgow, UK; Milan, Italy; Vienna, Austria), but also coexist with low-skill

\footnotetext{
${ }^{11}$ Information and Communication Technology (ICT).
} 
equilibria, leading to a situation of skill polarisation in these FRs. Cities are poles of attraction for highskill demand - especially in the business and ICT sectors - but these also inevitably coexist with a contrasting share of low-skill demand, especially in the service sector. To what extent it is desirable from a public perspective to meet the regional labour demands of low-skill jobs remains debatable: from a short-term perspective it might raise youth employment figures, although in the long-run it might trap young people in low-skill jobs. Moreover, it reveals the hidden consequences of the initial concept of a high-skill ecosystem (Finegold, 1999), questioning to what extent a high-skill ecosystem necessarily coexists with a regional low-skill demand and, consequently, with job and skill polarisation (Autor et al., 2006).

Beyond economic and employment consequences, the (mis)match between the supply and demand of skills also has implications for social inequalities (e.g. social class, gender and ethnicity) among young people across regions. While the specialised literature has already showed through statistical data analysis the prevalence of inequalities in labour market mismatches in European countries (Lindley, 2009; Storen \& Wiers-Jenssen, 2009; Van de Werfhorst, 2019), data on these inequalities at subnational level is rare or not comparable (Lewis, 2017). Through the qualitative interviews with key regional stakeholders, we investigate how these actors perceive the relationship between different types of skill mismatch and different types of social inequality at regional level.

In terms of social class inequality, the skill polarisation experienced in urban poles poses greater challenges for low-skilled youth, which tend to be associated with lower social class. While the number of young people with low-skill levels might remain quite stable in these FRs, the difficulties they face are increasing due to skill polarisation and the barriers to education and employment faced by the most disadvantaged. An illustrative example of this is the difficulty experienced by young people attempting to find an apprenticeship position in the FR of Bremen (Germany) and the risk of social exclusion associated with leaving education without a formal vocational qualification. Similarly, social background also seems to be a relevant indicator of limited chances of educational attainment in both Austrian FRs, as the early tracking of the education system generates social stratification between educational routes.

Following the 2008 global financial crisis, an increasingly relevant factor in many European regions is the lack of public investment in VET due to austerity measures. This phenomenon has direct influence on social class inequalities in the access to lifelong learning provision and in the opportunities to escape unemployment. In the FRs of Istria-County (Croatia) young people from disadvantaged backgrounds face significant financial difficulties in accessing the current offer of VET courses, limiting their opportunities to escape poor employment prospects and social exclusion. This is due to the introduction of student fees in VET courses in Croatia as part of the public sector austerity measures. The same policy changes have occurred in Italy, Portugal and some regions in Spain (Pastore, 2015, 2017). The impact of these measures on regional educational and employment inequalities is significantly more severe in those countries that already showed low public investment in VET.

Another social group significantly affected by low skill equilibrium, unemployment or over-qualification are youth from immigrant backgrounds, ethnic minorities and refugees. In the FRs of Plovdiv (Bulgaria) and Osijek-Baranja (Croatia), youth from the Roma community are more likely to be employed in low-skill sectors, while in the FRs of Bremen and Rhein-Main (Germany), Girona (Spain), Kainuu (Finland) and Vienna (Austria), non-EU migrants and refugees are more prone to being employed in low-skill jobs. In a similar vein, the intersection between skills and gender inequalities hits low-skilled young women 
particularly hard in the FR of Girona (Spain). Many of the initiatives to address skill shortages target unemployed or inactive young women, for example in the heavy industry of Aberdeen (Scotland) and Kainuu (Finland). However, the strong male dominance in manufacturing occupations limits the effectiveness of these policies and the employment opportunities of young women in these regions.

\section{Regional variation within skill formation regimes}

Although the institutional architecture of skill formation regimes is established at the national level, its effects on skill mismatch are significantly mediated by the labour markets and the socioeconomic characteristics of the regions where it operates. Based on the analysis of interviews with key regional stakeholders, in this section we discuss how the relationship between national skill formation regimes and skill mismatch vary across FRs with varying regional labour markets and socioeconomic conditions.

The Austrian case clearly illustrates how the collective regime of skill formation has divergent effects on skill mismatch across regions with different socioeconomic conditions and employment opportunities. The early division between vocational and academic tracks within the Austrian education and training system promotes a larger enrolment in vocational tracks and limits the possibility of later moving to an academic track. This institutional feature of the Austrian education and training system poses some restrictions for the FR of Vienna, where there is a shortage of youth with high-level qualifications and skills, particularly in R\&D and IT. Both public authorities and employers struggle to fill high-skill vacancies in this urban area and they report that employers try to fill these vacancies by attracting high-skilled immigrants. Conversely, in the FR of Upper Austria, the strong vocational orientation of the education and training system serves the technical and vocational skills demanded by the regional labour market, which occupies large share of the population in manufacturing (i.e. automotive). Therefore, the same skill formation arrangement provides different employment opportunities to youth in contrasting socioeconomic regions.

Similarly, Germany also presents a collective regime of skill formation with a strong vocational focus and early tracking. In the urban FR of Bremen the trend towards the 'academisation' of education to meet the increasing demand of highly-skilled workers in technology intensive industries is posing challenges to those young adults without an academic background. Conversely, in the German FRs of Rhein-Main, youth with vocational education and training have labour market opportunities that meet their skills due to the important logistical activity in the region. Thus, these findings suggest that the Austrian and German skill formation regimes struggle to provide 'second chance' opportunities for skills upgrading in dynamic urban regions with a large demand for highly-skilled workers.

The level of employers' involvement in skill formation through apprenticeships is one of the distinctive characteristics of the collective regime when compared to the statist and liberal regimes. In FRs with a comparatively underdeveloped apprenticeship system (e.g. Blagoevgrad in Bulgaria, Genoa and Milan in Italy, Osijek-Baranja in Croatia) key interviewees recognise this absence as the main cause of young people's struggle to transition from education to work. Policy actors in these regions seem to assume that a more developed apprenticeship system — including dual apprenticeships — would improve youths'

work-related skills, while also serving as a screening mechanism for employers when identifying potential employees.

However, interviewees in FRs with more developed and longstanding apprenticeship schemes highlighted their limitations. In the FRs of Bremen (Germany) and Vienna (Austria), there are not enough vacancies 
available to place all students. In the FR of Aberdeen (UK), one of the consequences of the 2014 oil and gas crisis has been a scarcity of apprenticeship vacancies. In the FR of Vienna (Austria), concerns have also been raised regarding quality assurance of the VET system: while the Austrian Government is willing to introduce more quality controls, employers are reluctant, especially small and medium enterprises (SMEs). In contexts where the apprenticeship system is the norm, employers consider its successful completion as a basic job requirement. Therefore, contrary to what is assumed by policy actors in some FRs, the existence of institutional frameworks that facilitate the involvement of employers in the funding of apprenticeships does not guarantee the availability of sufficient quality training opportunities for young people.

Employability training plays a central role in facilitating the transition of young people to the world of work in skill formation regimes with low involvement from employers. A crosscutting topic mentioned to different extents by interviewees across all FRs is the perceived relevance employers place on youths' communication, work-discipline and generally 'soft' skills. Beyond technical knowledge and skills, employers appreciate and require youths who can effectively communicate, behave and follow orders, as well as commit and have positive attitudes towards work. However, in several FRs, training policies focused on employability skills show limited effectiveness due to the poor labour market opportunities available to young people in regions (e.g. Girona, Spain; Genoa, Italy; Istria-County, Croatia) with a highly qualified labour force but with high significance of economic sectors like tourism and agriculture that do not demand high-skills. Upgrading the demand of skills in this type of region will require policies to go beyond the funding of these training opportunities and to invest in wider regional development plans with a focus on the creation of quality jobs.

Interestingly, employers' involvement in skill formation seems to be higher in FRs where one single industry has a dominant position in the labour market, even in the statist and liberal regimes. Tailoring the supply of skills to meet the needs of this specific industry seems to facilitate the match of skills and access to employment for young people. Nevertheless, employment dependence on specific industries also brings a set of negative implications mentioned by interviewees, such as the seasonality of agriculture (e.g. Litoral Alentejano and Vale do Ave, Portugal), the low-skill equilibrium of tourism (e.g. Girona and Málaga, Spain) or the hard working conditions of the metal and wood industries (e.g. Kainuu, Finland). Moreover, the dependence on a single regional industry makes youth more vulnerable to exogenous changes (e.g. oil and gas crisis in Aberdeen, UK) and might generate unbalanced demographic structures in terms of gender and age that translate into social inequalities, such as male dominated regions (e.g. oil and gas in Aberdeen, UK; metal and wood industry in Kainuu, Finland). Policymakers and experts interviewed in FRs experiencing skill shortages associated with a specific industry or season argue that young people do not find these jobs attractive from a career perspective, mainly because of the poor working conditions offered in these occupations (i.e. temporary contracts, hard work, low-skill, low salaries). Hence, even if there are market and employment opportunities in the region, young people do not consider or value educational investment in the sector because of the limited individual economic returns and undesired lifestyle.

The public commitment to the funding of VET is another characteristic that separates the liberal regime from the statist and collective regimes in the theoretical models. In the European context of postrecession and austerity measures, public funding restrictions do not only affect skill mismatch in the regions under the liberal model: insufficient funding of the VET system has been highlighted in several FRs for the insufficient offer of learning opportunities and the adoption of student fees, what has negative 
implications for social inequalities. For example, in the FR of Vienna (Austria), the access of non-EU migrants and refugees to publicly-funded training opportunities is generating tensions among social groups. Local actors reported that this competition for limited public resources is undermining the ability of most disadvantaged youth to acquire better skills. Another example can be found in the Croatian FR of Istria-County, where the very limited public funding of VET makes youth dependent on private funding. This represents a barrier to youth in financially vulnerable situations, which prevents them from undertaking this type of programme. In the Spanish FR of Málaga, the funding of some VET programmes has been discontinued since 2011 due to alleged corruption practices in the management of European Social Funding (ESF) finances. A number of FRs have also mentioned the relevance of ESF for the regional VET system (e.g. Blagoevgrad FR, Bulgaria), without which training opportunities for disadvantaged youth in the region would have been scarce or non-existent. Therefore, the limited public funding for training is an important challenge under the liberal regime, but their impact on social inequalities seems more significant in the regions with weaker economic development.

\section{Conclusions}

In this article we adopt the skill ecosystem approach to the comparative analysis of skill mismatch across European regions with different skill formation regimes. From a descriptive statistic characterisation, the cases under study show that countries that combine higher public commitment and private involvement in VET present lower levels of youth unemployment, but it also reveals large variation across regions within countries in terms of education and employment indicators. Regional stakeholders and documental data analyses reported skill shortages in sectors that demand high-skill levels (e.g. ICT), but also in lowskill sectors with high seasonal demand (e.g. tourism, agriculture). Skill surplus is a concern mainly for regions where the job opportunities available to higher education graduates are very limited, while skill polarisation is the norm in urban settings with economic sectors that demand high-skills. This translates into large inequality of opportunity and results among young people, particularly in highly-stratified education systems.

The interviews with regional stakeholders also showed that the institutional effects of skill formation regimes on skill mismatch vary largely according to the labour market and socioeconomic characteristics of regions. While the collective skill regime is associated with an adequate match of skills in regions with high demand for intermediate skills, it suffers from shortages of high skills in the most dynamic urban concentrations. The low involvement of employers in the statist and liberal regimes is seen by key actors as a major institutional obstacle to matching the demand and supply of skills in many regions, but this is not the case in regions with a predominant position of one single industry in the local economy. In these regions, the predominant industry creates its own mechanisms to coordinate the supply and demand of skills, although the limited career choices available are not always attractive to local young people. Finally, the impact of the recession has negative effects on the capacity of national policies to be effective in the most deprived regions. Austerity measures in the public sector widened inequality of opportunity and triggered social tensions regarding access to post-compulsory education and training. Likewise, the downturn in economic activity reduced the offer of apprenticeships and jobs available to those participating in employability training courses.

By adopting the skill ecosystem approach to the analysis of skill mismatch, the article makes a twofold contribution to the literature. Firstly, and in contrast to Human Capital Theory, our approach shows the importance of demand side factors (i.e. local labour market) in explaining skill shortage and skill surplus 
across European regions. It also shows that low and high-skill equilibria coexist in highly segmented labour markets, indicating the need for local skill strategies to go beyond the policy aim of raising skill levels and primarily focus on tackling social inequalities among young people. Secondly, our approach shows its potential for comparative research when combined with the analytical framework of skill formation regimes. National institutional arrangements certainly explain skill supply trends between countries, but they need to incorporate analysis of regional labour markets and socioeconomic conditions to explain the divergent effects of these institutional structures on skill mismatch across regions. Combining both approaches will also facilitate a fruitful interdisciplinary dialogue over an issue that remains underresearched in comparative education scholarship.

\section{References}

Almeida, R., Behrman, J. and Robalino, D. (2012), The Right Skills for the Job? Rethinking Training Policies for Workers, No. 70908, The World Bank, pp. 1-192.

Anderson, P. and Warhurst, C. (2012), Lost in translation? Skills policy and the shift to skill ecosystems, in Dolphin, T. and Nash, D. (Eds.), Complex New World. Translating New Economic Thinking into Public Policy, Institute for Public Policy Research, pp. 109-120.

Autor, D., Katz, L. and Kearney, M. (2006), The Polarization of the U . S . Labor Market, The American Economic Review, Vol. 96 No. 2, pp. 189-194.

Becker, G.S. (1964), Human Capital: A Theoretical and Empirical Analysis, with Special Reference to Education, The University of Chicago Press, London.

Bourdieu, P. (1984), Distinctions, Trans. Richard Nice. Cambridge: Harvard University Press.

Bourdieu, P. (1986), The forms of capital, in Richardson, J.C. (Ed.), The Handbook of Theory and Research for the Sociology of Education, Greenwood Publishing Group, Westport, CT, pp. 241-258.

Bowen, G.A. (2009), Document analysis as a qualitative research method, Qualtative Research Journal, Vol. 9 No. 2, pp. 27-40.

Bowles, S. and Gintis, H. (1976), Schooling in Capitalist America, Basic Books, New York.

Buchanan, J., Anderson, P. and Power, G. (2017), Skill Ecosystems, in Buchanan, J., Finegold, D., Mayhew, K. and Warhurst, C. (Eds.), The Oxford Handbook of Skills and Training, Oxford University Press, pp. 1-26.

Buchanan, J., Schofield, K., Briggs, C., Considine, G., Hager, P., Hawke, G., Kitay, J., et al. (2001), Beyond Flexibility: Skills and Work in the Future, NSW Board of Vocational Education and Training, Vol. October, available at:https://doi.org/10.1080/13636820.2013.867525.

Buchanan, J., Scott, L., Yu, S., Schutz, H. and Jakubauskas, M. (2010), Skills Demand and Utilisation: An International Review of Approaches to Measurement and Policy Development, OECD Local Economic and Employment Development (LEED) Working Papers, No. 04.

Busemeyer, M.R. and Iversen, T. (2011), Collective Skill Systems, Wage Bargaining, and Labor Market Stratification, in Busemeyer, M.R. and Trampusch, C. (Eds.), The Political Economy of Collective Skill Formation, Oxford University Press, Oxford, pp. 205-233.

Busemeyer, M.R. and Trampusch, C. (2012), The Comparative Political Economy of Collective Skill Formation, in Busemeyer, M.R. and Trampusch, C. (Eds.), The Political Economy of Collective Skill Formation, Oxford University Press, Oxford, pp. 1-44. 
Crouch, C., Finegold, D. and Sako, M. (2001), Are Skills the Answer?: The Political Economy of Skill Creation in Advanced Industrial Countries, Oxford University Press, Oxford.

Dalziel, P. (2015), Regional skill ecosystems to assist young people making education employment linkages in transition from school to work, Local Economy, Vol. 30 No. 1, pp. 53-66.

Dalziel, P. (2017), Education and Qualifications as Skills, in Buchanan, J., Finegold, D., Mayhew, K. and Warhurst, C. (Eds.), The Oxford Handbook of Skills and Training, Oxford University Press, pp. 1521.

Doeringer, P.B. and Piore, M.J. (1985), Internal Labor Markets and Manpower Analysis, ME Sharpe, Armonk, NY.

Estevez-Abe, M., Iversen, T. and Soskice, D. (2001), Social protection and the formation of skills: a reinterpretation of the welfare state, in Hall, P.A. and Soskice, D. (Eds.), Varieties of Capitalism: The Institutional Foundations of Comparative Advantage, Oxford University Press, Oxford, pp. 145-183.

European Commission. (2001), Making a European Area of Lifelong Learning a Reality, Commission of the European Communities, Brussels.

Eurostat. (2012), "Participation/enrolment of students at ISCED level 3-VOC - as \% of all students at ISCED level 3", available at: http://appsso.eurostat.ec.europa.eu/nui/submitViewTableAction.do (accessed 27 July 2018).

Eurostat. (2014a), "Early leavers from education and training by sex and NUTS 2 regions", available at: http://appsso.eurostat.ec.europa.eu/nui/show.do?dataset=edat_Ifse_16\&lang=en (accessed 27 July 2018).

Eurostat. (2014b), "Unemployment rates by sex, age and NUTS 2 regions (\%)", available at: http://appsso.eurostat.ec.europa.eu/nui/show.do?dataset=Ifst_r_Ifu3rt\&lang=en (accessed 27 July 2018).

Eurostat. (2014c), "Young people neither in employment nor in education and training by sex and NUTS 2 regions (NEET rates)", available at:

http://appsso.eurostat.ec.europa.eu/nui/show.do?dataset=edat_Ifse_22\&lang=en (accessed 27 July 2018).

Eurostat. (2017), "Public expenditure on education by education level and programme orientation - as \% of GDP", available at: http://appsso.eurostat.ec.europa.eu/nui/show.do?dataset=educ_uoe_fine06\&lang=en (accessed 27 July 2018).

Finegold, D. (1999), Creating self-sustaining, high-skill ecosystems, Oxford Review of Economic Policy, Vol. 15 No. 1, pp. 60-81.

Finegold, D. and Soskice, D. (1988), "The failure of training in Britain: analysis and prescription", Oxford Review of Economic Policy, Vol. 4 No. 3, pp. 21-53.

Froy, F., Giguere, S. and Hofer, A. (2009), Designing Local Skills Strategies, OECD, LEED, OECD Publishing, Paris.

Hodgson, A. and Spours, K. (2013), Tackling the crisis facing young people: Building 'high opportunity progression eco-systems', Oxford Review of Education, Vol. 39 No. 2, pp. 211-228. 
Hodgson, A. and Spours, K. (2015), An ecological analysis of the dynamics of localities: a 14+ low opportunity progression equilibrium in action, Journal of Education and Work, Routledge, Vol. 28 No. 1, pp. 24-43.

Klapka, P., Halás, M. and Torney, P. (2013), "Functional Regions: Concept and Types", In 16th International Colloquium on Regional Sciences, In 16th International Colloquium on Regional Sciences, Brno: Masarykova univerzita, pp. 94-101.

Lauder, H., Young, M., Daniels, H., Balarin, M. and Lowe, J. (2012), Educating for the Knowledge Economy? Critical Perspectives, edited by Lauder, H., Young, M., Daniels, H., Balarin, M. and Lowe, J., Routledge.

Lewis, J. (2017). Inequalities in European cities. In European Social Problems (pp. 71-94). Routledge.

Lindley, J. (2009). The over-education of UK immigrants and minority ethnic groups: Evidence from the Labour Force Survey. Economics of Education Review, 28(1), 80-89.

McGuinness, S. (2006), Overeducation in the labour market, Journal of Economic Surveys, Vol. 20 No. 3, pp. 387-418.

McQuaid, R.W. and Lindsay, C. (2005), The concept of employability, Urban Studies, Vol. 42 No. 2, pp. 197-219.

Mincer, J. (1974), Schooling, Experience and Earnings, Columbia University Press, New York.

OECD. (2001), Lifelong Learning for all policy directions, Education Policy Analysis, OECD Publishing, Paris, pp. 1-34.

OECD. (2012), Better Skills. Better Jobs. Better Lives. A Strategic Approach to Skills Policies, OECD Publishing.

OECD. (2015), "Enrolment in upper secondary education by programme orientation and age group (Table C 1.3)", Education at a Glance 2017: OECD Indicators, available at: https://www.oecdilibrary.org/education/education-at-a-glance-2017/c1-3-enrolment-in-upper-secondaryeducation-by-programme-orientation-and-age-group-2015_eag-2017-table134-en (accessed 27 July 2018).

Pastore, F. (2015). The European Youth Guarantee: labor market context, conditions and opportunities in Italy. IZA Journal of European Labor Studies, 4(1), 11.

Pastore, Francesco (2017) : Getting It Right: Youth Employment Policy within the EU, CESifo Forum, ISSN 2190-717X, ifo Institut - Leibniz-Institut für Wirtschaftsforschung an der Universität München, München, Vol. 18, Iss. 2, pp. 26-33

Payne, J. (2008), Skills in context: what can the UK learn from Australia's skill ecosystem projects?, Policy \& Politics, Vol. 36 No. 3, pp. 307-323.

Payne, J. (2009), Divergent skills policy trajectories in England and Scotland after Leitch, Policy Studies, Vol. 30 No. 5, pp. 473-494.

Schreier, M. (2012), Qualitative Content Analysis Practice, SAGE Publications Ltd, Thousand Oaks, CA.

Schultz, T.W. (1961), Investment in Human Capital, The American Economic Review, Vol. 51 No. 1, pp. 117.

Spence, M. (1973), Job Market Signaling, The Quarterly Journal of Economics, Vol. 87 No. 3, pp. 355-374. Storen, L. A., \& Wiers-Jenssen, J. (2009). Foreign diploma versus immigrant background: Determinants of labour market suc- cess or failure? Journal of Studies in International Education, 14(1), 29-49 
UNESCO (2011) Revision of the International Standard Classification of Education (ISCED). General Conference 36th Session, 36 C/19, 5 September 2011, Paris.

Van de Werfhorst, H. G. (2019). Early tracking and social inequality in educational attainment: Educational reforms in 21 European countries. American Journal of Education, 126(1). 